\title{
The Neuroprotective Effect of 2-(3-Pyridyl)-1- azabicyclo[3.2.2]nonane (TC-1698), a Novel $\alpha 7$ Ligand, Is Prevented through Angiotensin II Activation of a Tyrosine Phosphatase
}

\author{
Mario B. Marrero, Roger L. Papke, Balwinder S. Bhatti, Seán Shaw, and \\ Merouane Bencherif
}

Department of Pharmacology and Toxicology (M.B.M.), Vascular Biology Center, Medical College of Georgia, Augusta, Georgia (M.B.M., S.S.); Department of Physiology and Pharmacology, University of Florida, Gainesville, Florida (R.L.P.); and Department Preclinical Research (M.B.) and Drug Discovery and Development (B.S.B.), Targacept Inc., Winston-Salem, North Carolina

Received October 16, 2003; accepted December 10, 2003

\begin{abstract}
We have recently provided evidence for nicotine-induced complex formation between the $\alpha 7$ nicotinic acetylcholine receptor (nAChR) and the tyrosine-phosphorylated enzyme Janus kinase 2 (JAK2) that results in subsequent activation of phosphatidylinositol-3-kinase (PI-3-K) and Akt. Nicotine interaction with the $\alpha 7 \mathrm{nAChR}$ inhibits $\mathrm{A} \beta(1-42)$ interaction with the same receptor, and the $A \beta$ (1-42)-induced apoptosis is prevented through nicotine-induced activation of JAK2. These effects can be shown by measuring markers of cytotoxicity, including the cleavage of the nuclear protein poly(ADP-ribose) polymerase (PARP), the induction of caspase 3 , or cell viability. In this study, we found that 2-(3-pyridyl)-1-azabicyclo[3.2.2]nonane (TC-1698), a novel $\alpha 7$-selective agonist, exerts neuroprotective effects via activation of the JAK2/PI-3K cascade, which can be neutralized through activation of the angiotensin II (Ang II) $\mathrm{AT}_{2}$ receptor.
\end{abstract}

Vanadate not only augmented the TC-1698-induced tyrosine phosphorylation of JAK2 but also blocked the Ang II neutralization of TC-1698-induced neuroprotection against $A \beta(1-42)$ induced cleavage of PARP. Furthermore, when SHP-1 was neutralized via antisense transfection, the Ang II inhibition of TC-1698-induced neuroprotection against $A \beta$ (1-42) was prevented. These results support the main hypothesis that states that JAK2 plays a central role in the nicotinic $\alpha 7$ receptorinduced activation of the JAK2-PI-3K cascade in PC12 cells, which ultimately contribute to nAChR-mediated neuroprotection. Ang II inhibits this pathway through the $\mathrm{AT}_{2}$ receptor activation of the protein tyrosine phosphatase SHP-1. This study supports central and opposite roles for JAK2 and SHP-1 in the control of apoptosis and $\alpha 7$-mediated neuroprotection in PC12 cells.
Neuronal nicotinic acetylcholine receptors (nAChRs) are composed of various combinations of $\alpha$-subunits $(\alpha 2-\alpha 10)$ and $\beta$-subunits ( $\beta 2-\beta 4$ ) that form homo- or heteropentamers. The $\alpha 7 \mathrm{nAChR}$ forms functional homomeric ligand-gated ion channels that promote rapidly desensitizing $\mathrm{Ca}^{2+}$ influx, is widely expressed throughout the mammalian brain, and has been implicated in sensory gating, cognition, inflammation,

This work was supported by Targacept Inc. (to M.B.M., R.L.P., S.S.), and in part by National Institutes of Health Grants HL58139 and DK50268 (to M.B.M.), the American Heart Association Established Investigator Award (to M.B.M.), and National Institutes of Health Grant PO1 AG10485 (to R.L.P.).

Article, publication date, and citation information can be found at http://jpet.aspetjournals.org.

DOI: $10.1124 /$ jpet.103.061655 and neuroprotection (Kem, 2000; Bencherif and Schmitt, 2002; Kitagawa et al., 2003; Wang et al., 2003). The cholinergic deficit in neurodegenerative diseases has been clearly established and is the basis for current therapeutic strategies. There is an early and significant depletion of highaffinity nicotinic receptors in the brains of Alzheimer's patient's (Breese et al., 1997; Court et al., 2001), with a selective loss of $\mathrm{nAChR}$ predominating in brain regions with $\beta$-amyloid deposition. Several studies have shown cognitive improvement in rodents and primates, including humans, after administration of ligands targeting nicotinic acetylcholine receptors (Newhouse et al., 2001). In addition to their known symptomatic effects, neuronal nicotinic ligands have shown

ABBREVIATIONS: nAChR, nicotinic acetylcholine receptor; PI-3-K, phosphatidylinositol-3-kinase; MAPK, mitogen-activated protein kinase; JAK2, Janus kinase 2; PARP, poly(ADP-ribose) polymerase; Ang II, angiotensin II; PTPase, protein tyrosine phosphatase; PMSF, phenylmethylsulfonyl fluoride; PBS, phosphate-buffered saline; BSA, bovine serum albumin; MLA, methyllycaconitine; ACh, acetylcholine; PAGE, polyacrylamide gel electrophoresis; TTBS, Tris-Tween 20-buffered saline; IL, interleukin; PD 123,177, S(+)-1-[(4-amino-3-methylphenyl)methyl]-5-(diphenylacetyl)-4,5,6,7-tetrahydro-1H-imidazo-(4,5-c)]pyridine-6-carboxylic acid; AG-490, $\alpha$-cyano-(3,4-dihydroxy)- $N$-benzylcinnamide. 
neuroprotective activity in vitro and in vivo, suggesting an additional potential for disease modification (Donnelly-Roberts et al., 1996; Kihara et al., 2001; Nordberg et al., 2002). A direct interaction of the $\beta$-amyloid peptide with the $\alpha 7$ $\mathrm{nAChR}$ is suggested by recent findings. $\beta$-Amyloid peptide interacts with high affinity to the $\alpha 7 \mathrm{nAChR}$ and results in functional noncompetitive blockade in hippocampal neurons (Wang et al., 2000; Liu et al., 2001). In addition, nicotinicinduced neuroprotection against $\beta$-amyloid induced toxicity is suppressed by $\alpha$-bungarotoxin, and selective $\alpha 7 \mathrm{nAChR}$ agonists exert cytoprotective effects (Kem, 2000; Shaw et al., 2002).

Recent studies have reported that $\alpha 7$-mediated effects are mediated through phosphorylation of specific kinases such as Akt and subsequent activation of phosphatidylinositol 3-kinase (Kihara et al., 2001). Another study has shown that whereas nicotine activates the PI-3-K neuroprotective cascade, $\mathrm{A} \beta$ (1-42) chronically activates the mitogen-activated protein kinase (MAPK) cascade via the hippocampal $\alpha 7$ nAChR (Dineley et al., 2001). These findings were interpreted as evidence that chronic activation of the MAPK pathway by $\mathrm{A} \beta$ (1-42) eventually leads to the down-regulation of MAPK, which then sets up a positive feedback for $\mathrm{A} \beta$ accumulation and decreased phosphorylation of the cAMP regulatory protein (cAMP response element-binding protein), which is a necessary component for hippocampus-dependent memory formation in mammals. Nonetheless, these findings suggest that the $\alpha 7 \mathrm{nAChR}$ transduces signals to PI-3-K in a cascade, which ultimately contributes to a neuroprotective effect against $\mathrm{A} \beta$ (1-42).

There is recent evidence for the nicotine-induced complex formation between the $\alpha 7 \mathrm{nAChR}$ and the tyrosine-phosphorylated enzyme JAK2 that results in subsequent activation of PI-3-K and Akt (Shaw et al., 2002). In addition, nicotine interaction with the $\alpha 7 \mathrm{nAChR}$ is "dominant" over $\mathrm{A} \beta$ (1-42) interaction with the receptor, and the $\mathrm{A} \beta$ (1-42)-induced apoptosis is prevented through the nicotine-induced activation of JAK2. These effects can be shown by measuring markers of cytotoxicity such as the cleavage of the nuclear protein PARP, the induction of caspase 3, or cell viability. Finally, we reported that neuroprotective effects of nicotine could be neutralized through activation of the angiotensin $\mathrm{II}_{2} \mathrm{AT}_{2}$ receptor as evidenced by the reversal of JAK2 phosphorylation and inhibition of nicotineinduced neuroprotection (Shaw et al., 2002).

In this study, we report that 2-(3-pyridyl)-1-azabicyclo [3.2.2] nonane (TC-1698) is a highly selective nicotinic $\alpha 7$ receptor agonist that it activates JAK2 in PC12 cells and that this activation and downstream activation of PI-3-K and Akt are blocked by the specific inhibitor AG490. TC-1698-induced phosphorylation of JAK2 can be neutralized through angiotensin II (Ang II)-activation of the AT2 receptor and these effects are mediated through the protein tyrosine phosphatase (PTPase) SHP-1. Furthermore, usage of the PTPase SHP-1 antisense identified central and opposite roles for Jak2 and SHP-1 in the control of $\alpha 7$ nAChR-mediated PC12 cell survival and apoptosis.

\section{Materials and Methods}

\section{Synthetic Procedures}

The compound TC-1698 was prepared by the alkylation of the imine derived from 3-acetylpyridine and isopropylamine. Thus, the sequential treatment of imine with lithium diisopropyl amide and 4-(bromomethyl)oxane provided the key intermediate 1-(3-pyridyl)2-(4-oxanyl)propan-1-one, which was readily elaborated into the higher homolog of 2-(3-pyridyl)-quinuclidines. The construction of the [3.2.2] ring was accomplished by the transformation of the intermediate into oxime (1-pyridin-3-yl-3-(tetrahydropyran-4-yl)-propan1-one oxime) and then to the amine 1-pyridin-3-yl-3-(tetrahydropyran-4-yl)-propylamine. The amine upon heating with concentrated $\mathrm{HBr}$ in a sealed tube, followed by removal of the acid, and then refluxing with dilute ethanolic potassium carbonate yielded TC-1698 (Fig. 1). The structure was confirmed by ${ }^{1} \mathrm{H}$ an ${ }^{13} \mathrm{C}$ NMR, gas chro-

\section{$\underline{\text { Synthetic Scheme }}$}
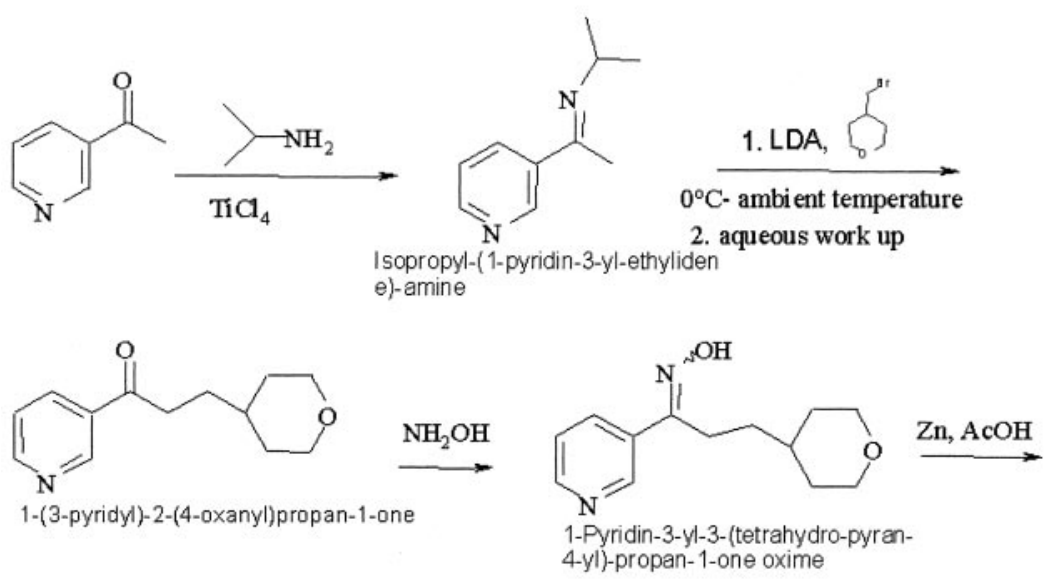

Fig. 1. Synthetic scheme for TC-1698.

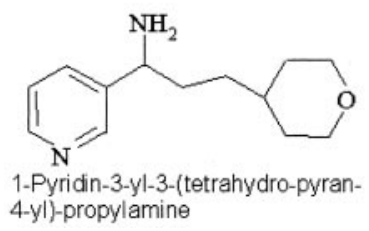

1. $\underset{\mathrm{HBr}, 120^{\circ} \text {, sealed tube }}{\longrightarrow}$<smiles>c1cncc([C@H]2CC3CCN2CC3)c1</smiles>

4-yl)-propylamine 
matography-mass spectrometry, and elemental analysis as 2-(3-pyridyl)-1-azabicyclo[3.2.2] nonane dihydrochloride (TC-1698) as $99.9 \%$ pure.

\section{Binding Studies}

Tissue Preparation. Rats were killed by decapitation after anesthesia with $70 \% \mathrm{CO}_{2}$. The brain was rapidly removed and placed on an ice-cold platform. The cerebral cortex, cerebellum, hippocampus, and striatum regions were dissected and stored at $-20^{\circ} \mathrm{C}$ until use for membrane preparation.

Preparation of Membranes from Rat Tissues. Tissue was homogenized in $10 \mathrm{vol}(\mathrm{w} / \mathrm{v})$ of ice-cold preparative buffer $(11 \mathrm{mM}$ $\mathrm{KCl}, 6 \mathrm{mM} \mathrm{KH}_{2} \mathrm{PO}_{4}, 137 \mathrm{mM} \mathrm{NaCl}, 8 \mathrm{mM} \mathrm{Na}_{2} \mathrm{HPO}_{4}, 20 \mathrm{mM}$ HEPES, $5 \mathrm{mM}$ iodoacetamide, $1.5 \mathrm{mM}$ EDTA, and $0.1 \mathrm{mM}$ PMSF, $\mathrm{pH} 7.4$, using a Polytron (Brinkmann Instruments, Westbury, NY) at setting 6 for $15 \mathrm{~s}$. The homogenate was then be centrifuged at 40,000g for 20 $\min$ at $4^{\circ} \mathrm{C}$, the pellet was resuspended in 20 vol of ice-cold water, and incubated for $20 \mathrm{~min}$ at $4^{\circ} \mathrm{C}$. The final pellet $(40,000 \mathrm{~g}$ for $20 \mathrm{~min}$ at $4^{\circ} \mathrm{C}$ ) was then be resuspended in preparative buffer and stored at $-20^{\circ} \mathrm{C}$. On the day of assay, tissue was thawed, centrifuged at $40,000 \mathrm{~g}$ for $20 \mathrm{~min}$ at $4^{\circ} \mathrm{C}$, and then resuspended in Dulbecco's phosphate-buffered saline (PBS, \#21300; Invitrogen, Carlsbad, CA), $\mathrm{pH} 7.4$, to a final concentration of 2 to $3 \mathrm{mg} / \mathrm{ml}$ total protein. PBS with $0.05 \%$ BSA was used to resuspend hippocampal membranes. Protein concentration was determined by the Bradford method using BSA as the standard.

$\left[{ }^{3} \mathrm{H}\right]$ Methyllycaconitine (MLA) and $\left[{ }^{3} \mathrm{H}\right]$ Nicotine Binding Assays. The $\left[{ }^{3} \mathrm{H}\right] \mathrm{MLA}$ binding assay was used to detect and quantify the $\alpha 7 \mathrm{nAChRs}$ in cerebral cortex, cerebellum, hippocampus, and striatum as described previously (Davies et al., 1999). Briefly, each sample ( $150 \mu \mathrm{l}$ of total volume) consisted of membrane suspension ( $\sim 150 \mu \mathrm{g}$ of protein), $5 \mathrm{nM}\left[{ }^{3} \mathrm{H}\right] \mathrm{MLA}$ for single-point screening, or 0.5 to $20 \mathrm{nM}$ for the saturation analysis. Nonspecific binding was determined in the presence of $10 \mu \mathrm{M}$ cold MLA. Binding reactions were conducted for $2 \mathrm{~h}$ at room temperature in 96 -well microtiter plates in triplicate. The binding reaction was terminated by rapid filtration onto Whatman GF/B glass fiber filters, presoaked in $0.3 \%$ polyethyleneimine, using a tissue harvester (Brandel Inc., Gaithersburg, $\mathrm{MD})$. After washing five times with $\sim 350 \mu \mathrm{l}$ of the ice-cold PBS, the filter plate was dried at $49^{\circ} \mathrm{C}$ for approx. $2 \mathrm{~h}$. MeltiLex A melt-on scintillator sheets (PerkinElmer Life Sciences, Boston, MA) were then be applied to the dry filters, and radioactivity bound to the membranes was determined by liquid scintillation counting. The $\left[{ }^{3} \mathrm{H}\right]$ nicotine binding assay used the same procedure to detect and quantify $\alpha 4 \beta 2$ nAChRs (Romano and Goldstein, 1980).

\section{Preparation of RNA}

The human nAChR clones were obtained from Dr. Jon Lindstrom (University of Pennsylvania, Philadelphia, PA) and the mouse muscle subunit clones were from Dr. Jim Boulter (University of California, Los Angeles, Los Angeles, CA); the mouse epsilon clone was provided by Dr. Paul Gardener (University of Massachusetts Medical School, Worcester, MA). After linearization and purification of cloned cDNAs, RNA transcripts were prepared in vitro using the appropriate mMessage mMachine kit from Ambion (Austin, TX).

\section{Expression in Xenopus Oocytes}

Mature $(>9 \mathrm{~cm}$ ) female $X$. laevis African toads (Nasco, Ft. Atkinson, WI) were used as a source of oocytes. Before surgery, frogs were anesthetized by placing the animal in a $1.5 \mathrm{~g} / \mathrm{l}$ solution of 3 -aminobenzoic acid ethyl ester for $30 \mathrm{~min}$. Oocytes were removed from an incision made in the abdomen. To remove the follicular cell layer, harvested oocytes were treated with $1.25 \mathrm{mg} / \mathrm{ml}$ collagenase from Worthington Biochemicals (Freehold, NJ) for $2 \mathrm{~h}$ at room temperature in calcium-free Barth's solution ( $88 \mathrm{mM} \mathrm{NaCl}, 10 \mathrm{mM}$ HEPES, $\mathrm{pH} 7.6,0.33 \mathrm{mM} \mathrm{MgSO}_{4}$, and $0.1 \mathrm{mg} / \mathrm{ml}$ gentamicin sulfate). Subsequently, stage 5 oocytes were isolated and injected with $50 \mathrm{nl}$ (5-20 ng) each of the appropriate subunit cRNAs. Recordings were made 1 to 15 days after injection.

\section{Electrophysiology}

Experiments were conducted using a beta version of OpusXpress 6000A (Axon Instruments, Union City, CA). OpusXpress is an integrated system that provides automated impalement and voltage clamp of up to eight oocytes in parallel. The beta unit used for these studies recorded from four cells simultaneously. Cells were automatically perfused with bath solution, and agonist solutions were delivered from a 96-well plate. Both the voltage and current electrodes were filled with $3 \mathrm{M} \mathrm{KCl}$. The agonist solutions were applied via disposable tips, which eliminated any possibility of cross-contamination. Drug applications alternated between ACh controls and experimental applications. Flow rates were set at $1 \mathrm{ml} / \mathrm{min}$. Cells were voltage-clamped at a holding potential of $-60 \mathrm{mV}$. Data were collected at $50 \mathrm{~Hz}$ and filtered at $20 \mathrm{~Hz}$. Drug applications were $20 \mathrm{~s}$ in duration followed by 383 -s washout periods for $\alpha 7$ receptors and $10 \mathrm{~s}$ with $383-\mathrm{s}$ wash periods for other subtypes.

\section{Experimental Protocols and Data Analysis}

Each oocyte received two initial control applications of ACh and an experimental drug application, and then a follow-up control application of $300 \mu \mathrm{M}$ ACh. The control ACh concentrations for $\alpha 1 \beta 1 \epsilon \delta$, $\alpha 3 \beta 4, \alpha 4 \beta 2, \alpha 3 \beta 2$, and $\alpha 7$ receptors were $30,100,10,30$, and $300 \mu \mathrm{M}$, respectively. These concentrations were determined to be the $\mathrm{EC}_{74}$, $\mathrm{EC}_{15}, \mathrm{EC}_{22}, \mathrm{EC}_{18}$, and $\mathrm{EC}_{100}$, respectively. Responses to TC-1698 applications were calculated relative to the preceding $\mathrm{ACh}$ control responses to normalize the data, compensating for the varying levels of channel expression among the oocytes. Drug responses were initially normalized to the ACh control response values and then adjusted to reflect the TC-1698 responses relative to the ACh maximums. Responses for $\alpha 7$ receptors were calculated as net charge over a 90-s interval, beginning with the drug application (Papke and Papke, 2002). For subtypes other than $\alpha 7$, responses were calculated from the peak current amplitudes. Means and S.E.M. were calculated from the normalized responses of at least three oocytes for each experimental concentration. The application of some experimental drugs caused the subsequent ACh control responses to be reduced, suggesting some form of residual inhibition (or prolonged desensitization). To measure the residual inhibitory effects, this subsequent control response was compared with the preapplication control ACh response.

For concentration-response relations, data derived from net charge analyses were plotted using KaleidaGraph 3.0.2 (Abelbeck Software, Reading, PA), and curves were generated from the Hill equation as follows:

$$
\text { Response }=\frac{I_{\max }[\text { agonist }]^{n}}{[\text { agonist }]^{n}+\left(\mathrm{EC}_{50}\right)^{n}}
$$

where $I_{\max }$ denotes the maximal response for a particular agonist/ subunit combination, and $n$ represents the Hill coefficient. $I_{\max }, n$, and the $\mathrm{EC}_{50}$ were all unconstrained for the fitting procedures. Negative Hill slopes were applied for the calculation of $\mathrm{IC}_{50}$ values.

\section{Materials and Chemicals}

Chemicals for electrophysiology were obtained from Sigma-Aldrich (St. Louis, MO) with the exception of TC-1698, which was synthesized. Other chemicals were purchased from Aldrich Chemical Co. (Milwaukee, WI). These were used without further purification, except in the case of tetrahydrofuran, which was dried by distillation from sodium and benzophenone. Merck silica gel 60 (70-230 mesh) was used for all the chromatographic purifications. Molecular weight standards, SDS, $N$ - $N^{\prime}$-methylene-bisacrylamide, $N, N, N^{\prime}, N^{\prime}$-tetramethylenediamine, protein assay reagents, and nitrocellulose membranes were purchased from Bio-Rad (Hercules, CA). Protein A/Gagarose was obtained from Santa Cruz Biotechnology, Inc. (Santa 
Cruz, CA), whereas Dulbecco's modified Eagle's medium (DMEM; Invitrogen), fetal bovine serum (Atlanta Biologicals, Norcross, GA), and trypsin and all medium additives were obtained from Mediatech (Herndon, VA). Monoclonal antibody to phosphotyrosine (PY20) and SHP-2 were procured from BD Biosciences Transduction Laboratories (Lexington, KY). PARP antibodies were purchased from New England Biolabs (Beverly, MA). Anti-phosphotyrosine JAK2 and JAK2 antibodies were obtained from BioSource International (Camarillo, CA). The Supersignal substrate chemiluminescence detection kit was obtained from Pierce Chemical (Rockford, IL). Goat antimouse IgG and anti-rabbit IgG were acquired from Amersham Biosciences Inc. (Princeton, NJ), and Tween 20, A $\beta$ (1-42) peptide, anti-A $\beta$ (1-42), and anti- $\alpha 7 \mathrm{nAChR}$ and all other chemicals were purchased from Sigma-Aldrich.

\section{Isolation and Culture of PC12 Cells}

PC12, rat pheochromocytoma cells, were maintained in proliferative growth phase in Dulbecco's modified Eagle's medium supplemented with $10 \%$ horse serum, $5 \%$ fetal calf serum, and antibiotics (penicillin/streptomycin) according to routine protocols (Bencherif et al., 1996).

\section{Western Blotting Studies of JAK2}

The tyrosine phosphorylation of JAK2 was determined in serumstarved PC12 cells stimulated with $10 \mu \mathrm{M}$ TC-1698 (0-60 min) in the presence or absence of $10 \mu \mathrm{M}$ (1-h preincubation) of the JAK2 specific inhibitor AG-490 (Meydan et al., 1996; Dicou et al., 2001). Although many tyrosine kinase inhibitors are often promiscuous in the enzyme they target, AG-490 is unique in that it does not inhibit other tyrosine kinases such as Lck, Lyn, Btk, Syk, Src, JAK1, or Tyk2 (Meydan et al., 1996). At the end of stimulation, cells were washed twice with ice-cold phosphate-buffered saline with $1 \mathrm{mM}$ $\mathrm{Na}_{3} \mathrm{VO}_{4}$. Each dish was then treated for $60 \mathrm{~min}$ with ice-cold lysis buffer (20 mM Tris-HCl, $\mathrm{pH}$ 7.4, $2.5 \mathrm{mM}$ EDTA, 1\% Triton X-100, $10 \%$ glycerol, $10 \mathrm{mM} \mathrm{Na} \mathrm{P}_{2} \mathrm{O}_{7}, 50 \mathrm{mM} \mathrm{NaF}, 1 \mathrm{mM} \mathrm{Na}_{3} \mathrm{VO}_{4}$, and 1 $\mathrm{mM}$ PMSF), and the supernatant fraction was obtained as cell lysate by centrifugation at $58,000 \mathrm{~g}$ for $25 \mathrm{~min}$ at $4^{\circ} \mathrm{C}$. Samples were resolved by $10 \%$ SDS-PAGE, transferred to a nitrocellulose membrane, and blocked by 60 -min incubation at $22^{\circ} \mathrm{C}$ in TTBS (Tris-buffered saline with $0.05 \%$ Tween $20, \mathrm{pH} 7.4$ ) plus $5 \%$ skimmed milk powder. The nitrocellulose membrane was incubated overnight at $4^{\circ} \mathrm{C}$ with affinity-purified anti-phospho specific JAK2 antibodies. The nitrocellulose membranes were washed 10 min twice with TTBS and incubated with goat anti-rabbit IgG horseradish peroxidase conjugate. After extensive washing, the bound antibody was visualized on a Kodak Biomax film using a Supersignal substrate chemiluminescence detection kit (Pierce Chemical).

\section{Immunoprecipitation Studies of SHP-1}

The cell lysate prepared as described above was incubated with $10 \mu \mathrm{g} / \mathrm{ml}$ anti-SHP-1 monoclonal antibodies at $4^{\circ} \mathrm{C}$ for $2 \mathrm{~h}$ and precipitated by addition of $50 \mu \mathrm{l}$ of protein $\mathrm{A} / \mathrm{G}$-agarose at $4^{\circ} \mathrm{C}$ overnight. The immunoprecipitates was recovered by centrifugation and washed three times with ice-cold wash buffer (Trisbuffered saline, $0.1 \%$ Triton X-100, $1 \mathrm{mM}$ PMSF, and $1 \mathrm{mM}$ $\mathrm{Na}_{3} \mathrm{VO}_{4}$ ). Immunoprecipitated proteins were dissolved in $100 \mu \mathrm{l}$ of Laemmli sample buffer, and $80 \mu \mathrm{l}$ of each sample was resolved by SDS-PAGE. Samples were transferred to a nitrocellulose membrane and blocked by 60 -min incubation at room temperature $\left(22^{\circ} \mathrm{C}\right)$ in TTBS plus $5 \%$ skimmed milk powder. The nitrocellulose membrane was then incubated overnight at $4^{\circ} \mathrm{C}$ with $10 \mu \mathrm{g} / \mathrm{ml}$ affinity-purified anti-phosphotyrosine antibodies. The nitrocellulose membranes were washed for 10 min twice with TTBS and incubated with goat anti-mouse IgG horseradish peroxidase conjugate. After extensive washing, the bound antibody was visualized on a Kodak Biomax film using a Supersignal substrate chemiluminescence detection kit (Pierce Chemical).

\section{SHP-1 Tyrosine Phosphatase Activity Assay}

SHP-1 activity was determined as described previously (Marrero et al., 1998). Briefly, SHP-1 proteins were immunoprecipitated with anti-SHP-1 antibodies from PC12 cell lysates, and the immunocomplexes were washed three times with ice-cold wash buffer and then three times with phosphatase buffer $(50 \mathrm{mM}$ HEPES, $60 \mathrm{mM} \mathrm{NaCl}, 60 \mathrm{mM} \mathrm{KCl}, 0.1 \mathrm{mM}$ PMSF, $10 \mu \mathrm{g} / \mathrm{ml}$ aprotinin, and $10 \mu \mathrm{g} / \mathrm{ml}$ leupeptin, $\mathrm{pH}$ 7.4). Phosphatase activity was measured by monitoring the rate of formation of $p$-nitrophenol by dephosphorylation of $p$-nitrophenyl phosphate. Immunocomplex pellets were thus resuspended in $100 \mu \mathrm{l}$ of phosphatase buffer containing $1 \mathrm{mg} / \mathrm{ml} \mathrm{BSA}, 5 \mathrm{mM}$ EDTA, and $10 \mathrm{mM}$ dithiothreitol. The reaction was initiated by the addition of $p$-nitrophenyl phosphate (10 $\mathrm{mM}$ final concentration). After a $30-\mathrm{min}$ incubation at room temperature, the reaction was stopped by the addition of $1 \mathrm{M} \mathrm{NaOH}$, and absorbance of the sample was determined at $410 \mathrm{~nm}$ in a spectrophotometer.

\section{Antisense against SHP-1}

An antisense oligonucleotide that targets the translational start site of the murine SHP-1 coding sequence ( 5 '-ACCTCACCATCCTTGGGGT- $3^{\prime}$ ) has been found to significantly reduce SHP-1 expression in human erythroleukemic SKT6 cells (Sharlow et al., 1997). Therefore, we have tested the effect of SHP-1 antisense phophorothiorate oligonucleotide on SHP-1 expression in PC12 cells. Cells were treated with the sense or antisense oligonucleotides $(10 \mu \mathrm{M})$ in LipofectAMINE for various times, SHP-1 was immunoprecipitated, and the immunoprecipitates were immunoblotted with anti-SHP-1 antibody.

\section{Assessment of PC12 Cell Apoptosis}

Apoptosis was determined by assessing the cleavage of the DNArepairing enzyme PARP using a Western blot assay. PARP (116 kDa) is an endogenous substrate for caspase-3, which is cleaved to a typical $85-\mathrm{kDa}$ fragment during various forms of apoptosis. PC12 cells were treated with $0.1 \mu \mathrm{M} \mathrm{A} \beta$ for $8 \mathrm{~h}$ in the presence or absence of TC-1698 and/or AG-490. The cells were collected, washed with PBS, and lysed in $1 \mathrm{ml}$ of SDS-PAGE sample buffer boiled for $10 \mathrm{~min}$. Total cell lysates (30 $\mu \mathrm{g}$ of protein) were separated by SDS-PAGE and transferred to nitrocellulose membranes. The membranes were blocked for $1 \mathrm{~h}$ at $25^{\circ} \mathrm{C}$ with $5 \%$ nonfat dry milk in TBST $(25 \mathrm{mM}$ Tris-HCl, pH 7.5, 0.5 M NaCl, and 0.05\% Tween 20). Membranes were incubated with primary PARP antibody specific for the $85-\mathrm{kDa}$ fragments for 2 to $3 \mathrm{~h}$ at $25^{\circ} \mathrm{C}$, rinsed with TBST, and incubated with secondary antibody for $1 \mathrm{~h}$ at $25^{\circ} \mathrm{C}$. Immunodetection was performed with appropriate antibody using an enhanced chemiluminescence system (Amersham Biosciences Inc.).

Caspase 3 enzyme activity was determined with a fluorogenic substrate for caspase- 3 in crude PC12 cell extracts. The caspase 3 fluorogenic peptide Ac-DEVD-AMC (Promega, Madison, WI) contains the specific caspase 3 cleavage sequence (DEVD) coupled at the $\mathrm{C}$-terminal to the fluorochrome 7-amino-4-methyl coumarin. The substrate emits a blue fluorescence when excited at a wavelength of $360 \mathrm{~nm}$. When cleaved from the peptide by the caspase 3 enzyme activity in the cell lysate, free 7-amino-4-methyl coumarin is released and can be detected by its yellow/green emission at 460 $\mathrm{nm}$. Appropriate controls included a reversible aldehyde inhibitor of caspase 3 to assess the specific contribution of the caspase 3 enzyme activity (data not shown). Fluorescence units were normalized relative to total protein concentration of the cell extract. We performed the assays in triplicate and repeated the experiments six times. 
A

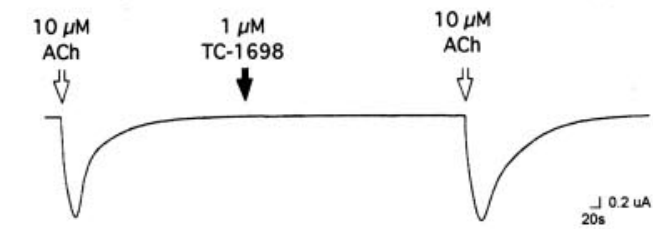

$\alpha 4 \beta 2 \mathrm{nAChR}$

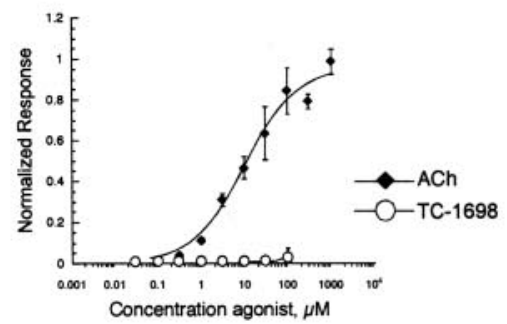

\section{$\alpha 7 \mathrm{nAChR}$}

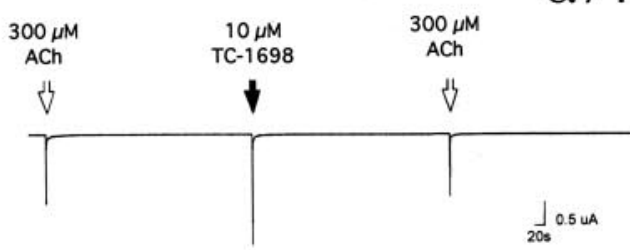

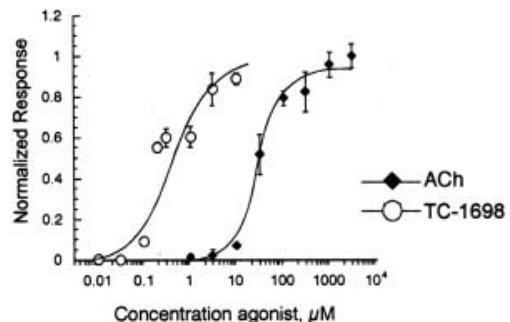

$\alpha 3 \beta 2 \mathrm{nAChR}$

C

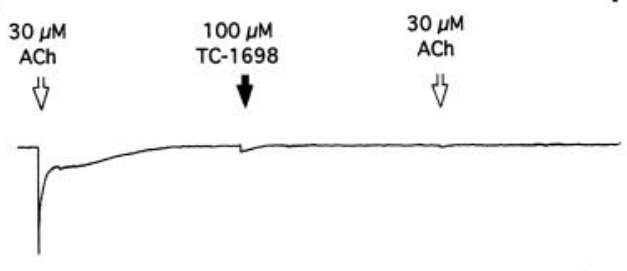

$\int_{205}^{\perp} 0.2$ UA

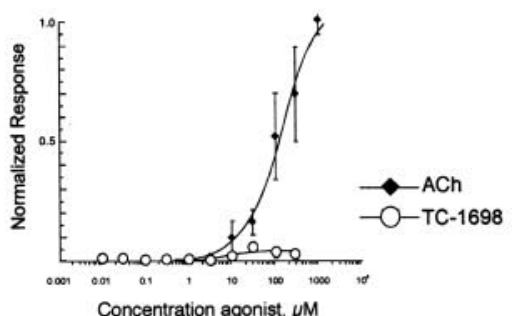

D

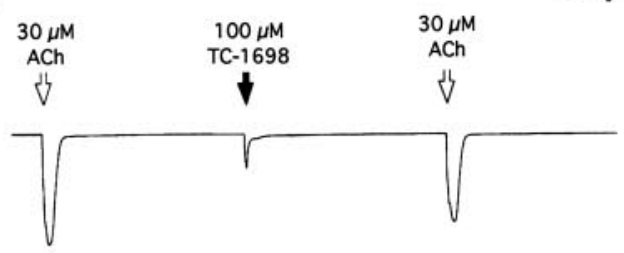

\rfloor$_{20 \mathrm{~s}} 1 \mu \mathrm{A}$

\section{$\alpha 3 \beta 4$ nAChR}

E

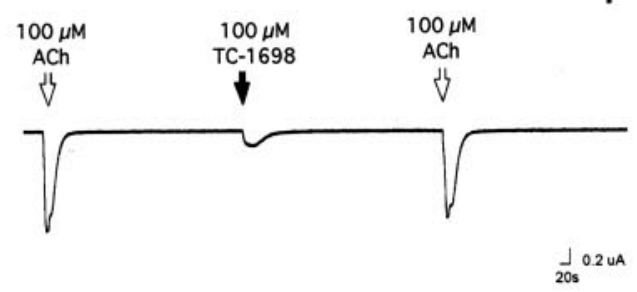

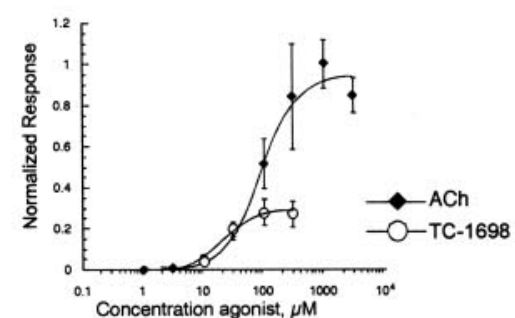

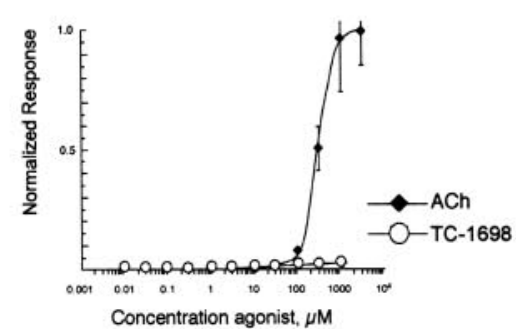

Fig. 2. Effects of TC-1698 on nAChR. Responses of oocytes expressing human $\alpha 4 \beta 2$ receptors (A), human $\alpha 7$ receptors oocytes (B), human $\alpha 3 \beta 2$ (C), mouse muscle-type receptors $\alpha 1 \beta 1 \epsilon \delta$ (D), or human $\alpha 3 \beta 4$ (E). Representative raw data traces are shown on the left, and concentration-response curves to the application of either ACh or TC-1698 are shown on the right. In the concentration-response curves, each point is the mean response of at least three cells ( \pm S.E.M.). Each measurement was initially normalized to the ACh control response measured in the same cell. These values were subsequently scaled by the ratio of the $\mathrm{ACh}$ controls to the $\mathrm{ACh}$ maximum response. 


\section{$\alpha 4 \beta 2 \mathrm{nAChR}$}

A
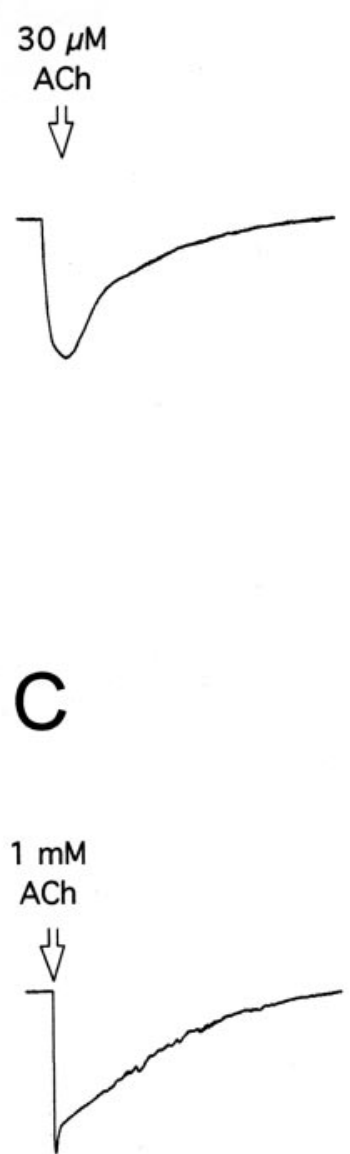
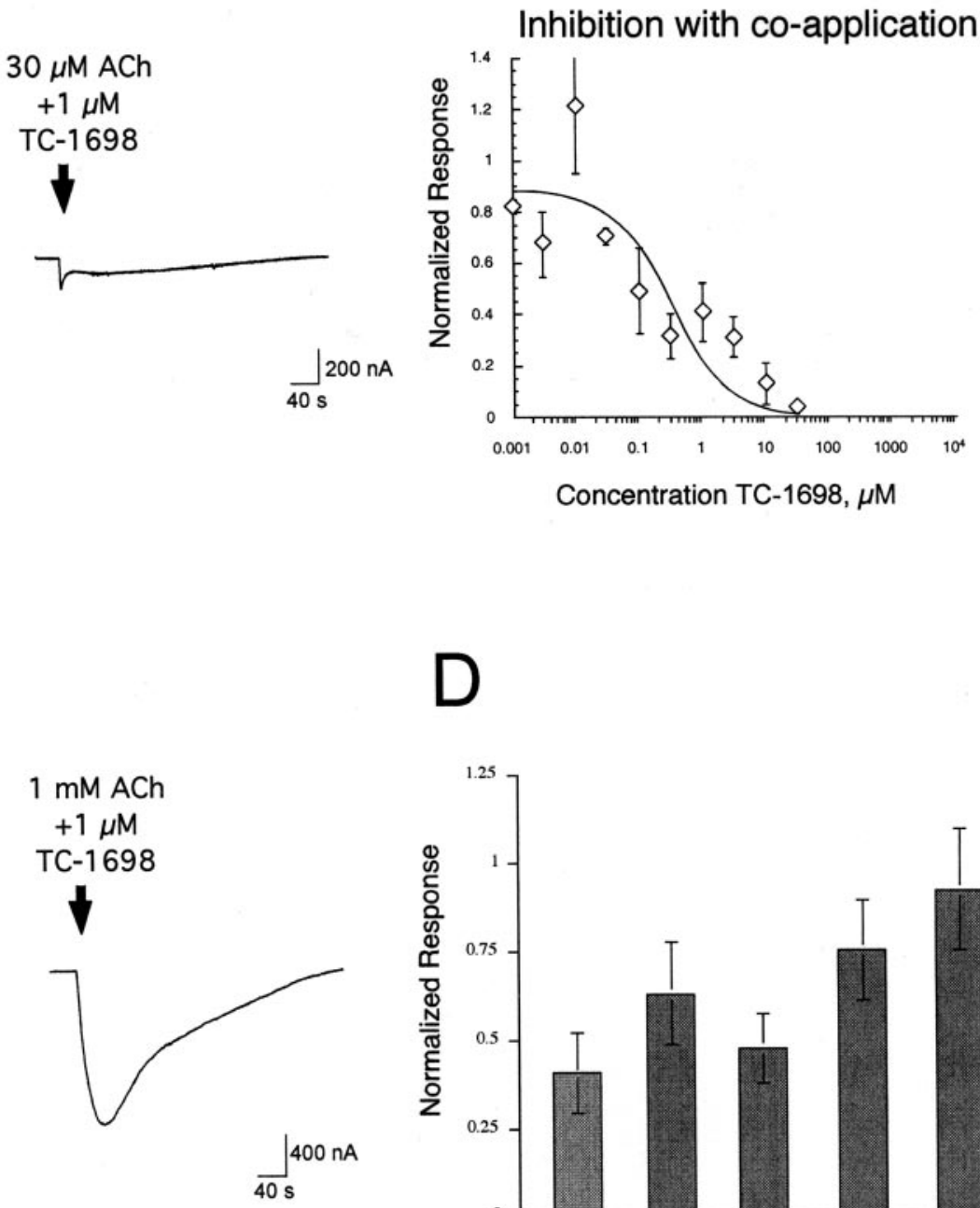

B

Fig. 3. ACh and TC-1698 coapplication responses of $\alpha 4 \beta 2$ nAChR. A, effect of coapplication of $1 \mu \mathrm{M}$ TC-1698 on the response inhibition of an oocyte expressing human $\alpha 4 \beta 2$ receptors. On the left is shown the response to $30 \mu \mathrm{M}$ ACh alone. On the right is the response of the same oocyte to $30 \mu \mathrm{M}$ ACh plus $1 \mu \mathrm{M}$ TC-1698. B, inhibition curve for the effect of increasing concentrations of TC- 1698 on the responses of $\alpha 4 \beta 2$-expressing oocytes to the application of $30 \mu \mathrm{M}$ ACh coapplied with TC-1698. Each point is the mean response of at least three cells $( \pm$ S.E.M.). Each measurement is expressed relative to the ACh control response measured in the same cell before the coapplication of ACh and TC-01698. C, peak responses to high concentrations of ACh are relatively unaffected by coapplication of TC-1698. On the left is shown the response to $1 \mathrm{mM}$ ACh alone. On the right is the response of the same oocyte to $1 \mathrm{mM}$ ACh plus $1 \mu \mathrm{M}$ TC-1698. D, effect of $1 \mu \mathrm{M}$ TC-1698 on the inhibition of responses to varying concentrations of ACh coapplied to oocytes expressing human $\alpha 4 \beta 2$ receptors. Data are normalized to the responses of the same oocytes to ACh alone applied at the indicated concentrations. Each bar is the mean response of at least three cells ( \pm S.E.M.).

\section{Data Analysis}

All statistical comparisons were made using Student's $t$ test for paired data and analysis of variance. Significance was $p<0.05$.

\section{Results}

\section{Electrophysiological Studies Indicate That TC-1698 Is a Selective Agonist to the $\alpha 7$ nAChR}

$\boldsymbol{\alpha} 4 \boldsymbol{\beta} 2$ nAChR. TC-1698 had little or no agonist activity when applied alone at concentrations up to $100 \mu \mathrm{M}$ to oocytes expressing $\alpha 4 \beta 2$ receptors ( $<3 \%$ ACh maximum; Fig. 2). However, subsequent to the application of TC-1698, we noted that subsequent $\mathrm{ACh}$ control responses were progressively inhibited $\left(\mathrm{IC}_{50}>30 \mu \mathrm{M}\right.$, Fig. 3). Because we noted an inhibition of $\alpha 4 \beta 2$ control ACh responses after the application of TC-1698, we further investigated whether TC-1698 might function as an antagonist of $\alpha 4 \beta 2 \mathrm{nAChR}$. When TC-1698 was coapplied at increasing concentration with $30 \mu \mathrm{M}$ ACh, we noted a concentration-dependent inhibition of the ACh response $\left(\mathrm{IC}_{50} \approx 300 \mathrm{nM}\right.$; Fig. 3). To further investigate the 
TABLE 1

Binding selectivity profile of TC-1698

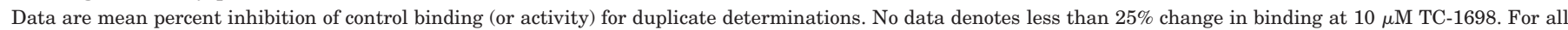
non-nicotinic receptors tested, TC-1698 had an $\mathrm{IC}_{50}>1 \mu \mathrm{M}$.

\begin{tabular}{|c|c|c|}
\hline Binding Site & Radioligand & Inhibition (Percentage at $10 \mu \mathrm{M}$ ) \\
\hline Acetylcholinesterase & Acetylthiocholine & \\
\hline Adenosine, nonselective & {$\left[{ }^{3} \mathrm{H}\right] \mathrm{NECA}$} & \\
\hline Adrenergic $\alpha_{1}$ (rat cortex) & {$\left[{ }^{3} \mathrm{H}\right] \mathrm{MeOxy}-$ prazocin } & \\
\hline Adrenergic $\alpha_{2}$ (rat cortex) & {$\left[{ }^{3} \mathrm{H}\right] \mathrm{RX}-821002$} & \\
\hline Adrenergic $\beta$ nonselective & {$\left[{ }^{3} \mathrm{H}\right] \mathrm{DHA}$} & \\
\hline Angiotensin $\mathrm{AT}_{1}$ (human) & {$\left[{ }^{125} \mathrm{I}\right]$-(Sar1-Ile8) angiotensin } & \\
\hline Angiotensin $\mathrm{AT}_{2}$ & {$\left[{ }^{125} \mathrm{I}\right] \mathrm{Tyr} 4$-angiotensin II } & \\
\hline Calcium channel, type L & {$\left[{ }^{3} \mathrm{H}\right]$ Nitrendipine } & \\
\hline Bradykinin, BK2 & {$\left[{ }^{3} \mathrm{H}\right]$ Bradykinin } & \\
\hline Calcium channel, type $\mathrm{N}$ & {$\left[{ }^{3} \mathrm{H}\right]$ conotoxin GVIA } & \\
\hline Cholecystokinin, CCK1 (CCKA) & {$\left[{ }^{125} \mathrm{I}\right] \mathrm{CCK}-8$} & \\
\hline Cholecystokinin, CCK2 (CCKB) & {$\left[{ }^{125} \mathrm{I}\right] \mathrm{CCK}-8$} & \\
\hline Choline acetyltransferase & {$\left[{ }^{14} \mathrm{C}\right]$-Acetyl Coenzyme } & \\
\hline Glutamic acid decarboxylase & {$\left[{ }^{14} \mathrm{C}\right]$-Glutamic Acid } & \\
\hline Corticotropin-releasing factor & {$\left[{ }^{3} \mathrm{H}\right]-\mathrm{Tyr} 0-\mathrm{oCRF}$} & \\
\hline Dopamine D3 (rat recombinant) & {$\left[{ }^{3} \mathrm{H}\right]$ Spiperone } & \\
\hline Dopamine transporter & {$\left[{ }^{3} \mathrm{H}\right]-$ WIN 35,428} & \\
\hline Endothelin ET-A (Human) & {$\left[{ }^{125} \mathrm{I}\right]$-Endothelin 1} & \\
\hline Endothelin ET-B (Human) & {$\left[{ }^{125} \mathrm{I}\right]$-Endothelin 1} & \\
\hline GABA (rat cortex) & {$\left[{ }^{3} \mathrm{H}\right]-\mathrm{GABA}$} & \\
\hline Estrogen & {$\left[{ }^{125} \mathrm{I}\right] 3,17 \mathrm{~B}-$ Estradiol, 16a } & \\
\hline GABA-A, BDZ, $\alpha 1$, central & {$\left[{ }^{3} \mathrm{H}\right]$-Flunitrazepam } & \\
\hline GABA-B transporter (rat cortex) & {$\left[{ }^{3} \mathrm{H}\right]-\mathrm{CGP} 5462 \mathrm{~A}$} & \\
\hline Galanin, nonselective & {$\left[{ }^{125} \mathrm{I}\right]$ Galanin } & \\
\hline Glycine (rat spinal cord) & {$\left[{ }^{3} \mathrm{H}\right]-$ Strychnine } & \\
\hline Histamine $\mathrm{H} 1$ periph. (guinea pig lung) & {$\left[{ }^{3} \mathrm{H}\right]$-Pyrilamine } & \\
\hline Histamine $\mathrm{H} 1$ & {$\left[{ }^{3} \mathrm{H}\right]$-Pyrilamine } & \\
\hline Histamine H2 & {$\left[{ }^{3} \mathrm{H}\right]$-Pyrilamine } & 39 \\
\hline Histamine H3 & {$\left[{ }^{3} \mathrm{H}\right]$-Pyrilamine } & 60 \\
\hline Leukotriene B4, LTB4 & {$\left[{ }^{3} \mathrm{H}\right]-\mathrm{LTB} 4$} & \\
\hline Leukotriene D4, LTD4 & {$\left[{ }^{3} \mathrm{H}\right]-\mathrm{LTD} 4$} & \\
\hline Melatonin ML1 (chicken brain) & {$\left[{ }^{125} \mathrm{I}\right]$-Iodomelatonin } & \\
\hline Monoamine oxidase A, peripheral & {$\left[{ }^{14} \mathrm{C}\right]-5 \mathrm{HT}$} & \\
\hline Monoamine oxidase $\mathrm{B}$, peripheral & {$\left[{ }^{14} \mathrm{C}\right]$ phenylethylamine } & \\
\hline Muscarinic, M1 (human recombinant) & {$\left[{ }^{3} \mathrm{H}\right]-\mathrm{QNB}$} & \\
\hline Muscarinic, M2 (human recombinant) & {$\left[{ }^{3} \mathrm{H}\right]-\mathrm{QNB}$} & 46 \\
\hline Muscarinic, nonselective central & {$\left[{ }^{3} \mathrm{H}\right]-\mathrm{QNB}$} & \\
\hline Muscarinic, nonselective, peripheral & {$\left[{ }^{3} \mathrm{H}\right]-\mathrm{QNB}$} & \\
\hline Neurokinin, NK1 & {$\left[{ }^{3} \mathrm{H}\right]-\mathrm{SP}$} & \\
\hline Neurokinin, NK2 (human recombinant) & {$\left[{ }^{3} \mathrm{H}\right]-\mathrm{NKA}$} & \\
\hline Neurokinin, NK3 (NKB) & {$\left[{ }^{3} \mathrm{H}\right]$-Eledoisin } & \\
\hline Nicotinic (rat cortex) & {$\left[{ }^{3} \mathrm{H}\right]$-Cytisine } & 104 \\
\hline Norepinephrine transporter (rat cortex) & {$\left[{ }^{3} \mathrm{H}\right]$-Nisoxetine } & \\
\hline NOS (neuronal-binding) & {$\left[{ }^{3} \mathrm{H}\right]-\mathrm{NOARG}$} & \\
\hline Opioids (rat cortex) & {$\left[{ }^{3} \mathrm{H}\right]$-Naloxone } & \\
\hline Oxytocin (rat uterus) & {$\left[{ }^{3} \mathrm{H}\right]$-oxytocin } & \\
\hline Platelet-activating factor, $\mathrm{PAF}$ & Hexadecyl- $\left[{ }^{3} \mathrm{H}\right]$-acetyl-PAF & \\
\hline Potassium $\mathrm{K}_{\mathrm{ATP}}$ channels (rat cortex) & {$\left[{ }^{3} \mathrm{H}\right]$-Glibenclamide } & \\
\hline Potassium $\mathrm{K}_{\mathrm{VI}}$ channels (rat cortex) & {$\left[{ }^{125} \mathrm{I}\right]-$ Apamin } & \\
\hline Potassium $\mathrm{K}_{\mathrm{VS}}$ channels (rat cortex) & {$\left[{ }^{125} \mathrm{I}\right]-$-Charybdotoxin } & \\
\hline Serotonin transporter & {$\left[{ }^{3} \mathrm{H}\right]$-Citalopram, N-methyl } & \\
\hline Serotonin, nonselective & {$\left[{ }^{125} \mathrm{I}\right]-\mathrm{LSD}$} & \\
\hline Sigma (rat cortex) & {$\left[{ }^{3} \mathrm{H}\right]-\mathrm{DTG}$} & 35 \\
\hline Sodium channels site 2 (rat cortex) & {$\left[{ }^{3} \mathrm{H}\right]$-Batrachotoxin } & \\
\hline Testosterone (cytosolic) & {$\left[{ }^{3} \mathrm{H}\right]$-Methyltrienolone } & \\
\hline Thromboxane A2 (Human) & {$\left[{ }^{3} \mathrm{H}\right]-\mathrm{SQ} 29,548$} & \\
\hline Thyrotropin-releasing hormone, TRH & {$\left[{ }^{3} \mathrm{H}\right]-(3 \mathrm{MeHis} 2) \mathrm{TRH}$} & \\
\hline Vasoactive intestinal peptide & {$\left[{ }^{125} \mathrm{I}\right]-\mathrm{VIP}$} & \\
\hline Vasopressin $\mathrm{V}_{1}$ (rat aortic A7r5 cells) & {$\left[{ }^{3} \mathrm{H}\right]-\mathrm{AVP}$} & \\
\hline
\end{tabular}

nature of the TC- 1698 inhibition of $\alpha 4 \beta 2$ ACh responses, we conducted some competition experiments. We noted that when TC-1698 at a fixed concentration of $1 \mu \mathrm{M}$ was coapplied with increasing concentrations of $\mathrm{ACh}$, there was inhibition of the response to low concentrations of ACh but not to high concentrations of $\mathrm{ACh}$, consistent with competitive inhibition (Fig. 3; Table 1).

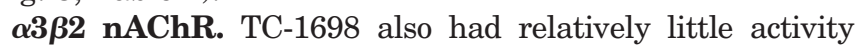
when applied alone at concentrations up to $300 \mu \mathrm{M}$ to oocytes expressing $\alpha 3 \beta 2$ receptors ( $<5 \%$ ACh maximum; Fig. 2; Table 1). However, subsequent $\mathrm{ACh}$ responses were decreased after TC-1698 was applied alone ( $\mathrm{IC}_{50} \approx 25 \mu \mathrm{M}$; data not shown).

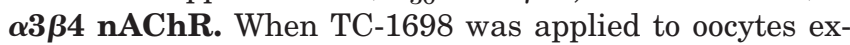
pressing $\alpha 3 \beta 4$ receptors, very small currents were observed at very high concentrations $\left(I_{\max } \approx 5 \%\right.$ that of $\mathrm{ACh}, \mathrm{EC}_{50}=$ $1600 \mu \mathrm{M}$; Fig. 2). After the application of TC-1698 to oocytes expressing $\alpha 3 \beta 4$ receptors, little or no inhibition of subsequent $\mathrm{ACh}$ control responses was observed (data not shown). 


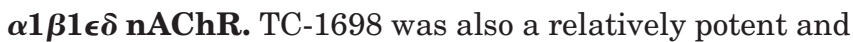
modestly efficacious agonist of mouse muscle nAChR expressed in Xenopus oocytes. The maximum current was $28 \pm$ $1 \%$ of the maximum response to $\mathrm{ACh}$. TC-1698 had an $\mathrm{EC}_{50}$ value of $20 \pm 1.3 \mu \mathrm{M}, 50$ times less potent than for $\alpha 7$, compared with $82 \mu \mathrm{M}$ for ACh (Fig. 2).

$\boldsymbol{\alpha} \mathbf{7} \mathbf{n A C h R}$. Whereas TC-1698 had very little agonist activity with $\beta$-subunit-containing neuronal $\mathrm{nAChR}$, it seemed to be a potent and efficacious agonist of $\alpha 7$-type receptors. It produced maximum responses equivalent to those produced by ACh (i.e., $I_{\max } \geq 100 \%$ compared to ACh). TC-1698 was approximately 30 -fold more potent than $\mathrm{ACh}$, with an $\mathrm{EC}_{50}$ value of $440 \pm 14 \mathrm{nM}$, compared with $30 \mu \mathrm{M}$ for ACh (Fig. 2). TC-1698 application to $\alpha 7$-expressing oocytes produced no significant residual inhibition of subsequent ACh responses (data not shown). In Fig. 2A, note that because TC-1698 is a far more potent agonist than ACh, although the TC-1698 peak current is larger than that of the ACh controls, the net charge is roughly equivalent to that evoked by the $300 \mu \mathrm{m}$ ACh control.

\section{Activity Profile for TC1698 in Clonal Cells}

The affinity of TC-1698 for brain nAChR was determined by radioligand binding studies. Membranes prepared from rat hippocampus, a brain region enriched in $\alpha 7 \mathrm{nAChR}$, were used along with $\left[{ }^{3} \mathrm{H}\right] \mathrm{MLA}$ as labeling agent and TC-1698 exhibited a $K_{\mathrm{i}}$ of $11 \pm 1.7 \mathrm{nM}$ in this preparation $(n=4)$. The potency and efficacy of TC-1698 at peripheral nAChR was assessed using radioactive rubidium efflux assays in rat and human cell lines expressing muscle- and ganglion-type nAChR (Lukas and Cullen, 1988). TC-1698 is a poor activator of rat and human ganglion-type $\mathrm{nAChR}$ and human muscle type receptors expressed in clonal cell lines. At $100 \mu \mathrm{M}$, activation of either human muscle receptor (human TE671/ $\mathrm{RD}$ ) or ganglion-type receptors (rat PC12 and human $\mathrm{SH}$ SY5Y cells) were below $20 \%$ of that of nicotine. The intrinsic activity of TC-1698 at brain nAChR was assessed using $\left[{ }^{3} \mathrm{H}\right]$ dopamine release from rat striatal synaptosomes. TC1698 resulted in no significant activation of dopamine release, suggesting a lack of agonist activity at $\alpha 4 \beta 2 \mathrm{nAChR}$.

A binding profile was conducted to evaluate the interaction of TC-1698 with other receptors, transporters, enzymes, or ion channels. With the exception of nicotinic receptors at which binding was totally displaced, $10 \mu \mathrm{M}$ TC-1698 had no or very low affinity for all binding sites examined (Table 2).

TABLE 2

Activation parameters for TC-1698

\begin{tabular}{lcll}
\hline & $I_{\max }$ & \multicolumn{1}{c}{$n$} & \multicolumn{1}{c}{$\mathrm{EC}_{50}$} \\
\hline$\alpha 4 \beta 2$ & $<0.05$ & $\mathrm{NA}^{a}$ & $\left(.03 \mathrm{ACh} I_{\max } @ 100 \mu \mathrm{M}\right)$ \\
$\alpha 7$ & 1.0 & 0.9 & $345 \pm 110 \mathrm{nM}$ \\
$\alpha 3 \beta 2$ & $\leq 0.06$ & $\mathrm{NA}^{a}$ & $\left(0.05-0.02 \mathrm{ACh} I_{\max } 30-300 \mu \mathrm{M}\right)^{a}$ \\
$\alpha 1 \beta 1 \epsilon \delta$ & 0.28 & 2.0 & $20 \pm 1.3 \mu \mathrm{M}$ \\
$\alpha 3 \beta 4$ & $<0.05$ & $\mathrm{NA}^{a}$ & $\left(.02 \mathrm{ACh} I_{\max } @ 1 \mathrm{mM}\right)$ \\
\hline
\end{tabular}

${ }^{a}$ NA, not available, that is, the responses were too low for the data to give a meaningful curve fit.

${ }^{b}$ Between 30 and $300 \mu \mathrm{M}$ there were detectable responses that varied between 0.05 and 0.02 of the $\mathrm{ACh}$ maximum response; however, responses to $30 \mu \mathrm{M}$ and 100 $\mu \mathrm{M}$ were not statistically different and responses to $300 \mu \mathrm{M}$ were, if anything, less than the responses to 100 and $30 \mu \mathrm{M}$.

\section{Effects of the JAK2 Inhibitor AG-490 on TC-1698-Induced Tyrosine Phosphorylation of JAK2 and PI-3-Kinase and Serine Phosphorylation of Akt in PC12 Cells}

Enzymatic activation of JAK2 was determined via its tyrosine phosphorylation. The tyrosine phosphorylated JAK2 sometimes shows up as a doublet or shifts in its migration in the SDS-PAGE gel. These anomalies may be due to either proteolysis of JAK2 or different levels of serine phosphorylation of the enzyme (Marrero et al., 1998; Shaw et al., 2002). In this study, we found that JAK2 is tyrosine phosphorylated in response to the $\alpha 7$ receptor specific ligand TC-1698 (10 $\mu \mathrm{M}$ ) within $5 \mathrm{~min}$, and this activation remained above basal levels even after longer exposure $(60 \mathrm{~min})$ to compound TC1698 (Fig. 4). We also found that preincubation for $1 \mathrm{~h}$ with the JAK2 inhibitor AG-490 (10 $\mu \mathrm{M})$ inhibited the TC-1698induced JAK2 tyrosine phosphorylation, the tyrosine phosphorylation of PI-3-K, and the serine phosphorylation of Akt (Fig. 4). These results are similar in their kinetics of JAK2 activation to our previous reported results when we used nicotine (Shaw et al., 2002).

\section{Effects of Ang II Pretreatment with or without Ang II Receptor Antagonists on TC-1698-Induced Tyrosine Phosphorylation of JAK2}

Preincubation of PC12 cells with Ang II blocked TC-1698induced tyrosine phosphorylation of JAK2 (Fig. 5A). This inhibition was completely prevented by preincubation with an $\mathrm{AT}_{2}$ antagonist (PD 123177 at $100 \mathrm{nM}$ ) but not by an $\mathrm{AT}_{1}$ antagonist (candesartan at $100 \mathrm{nM}$ ) (Fig. 5A), consistent with the Ang II receptor phenotype expressed in PC12 cells. Consistent with our data indicating that TC-1698 is a potent selective agonist of $\alpha 7$-type receptors, TC-1698-induced activation of JAK2 was blocked by the $\alpha 7$ antagonist $\alpha$-bungoratoxin (Fig. 5C).

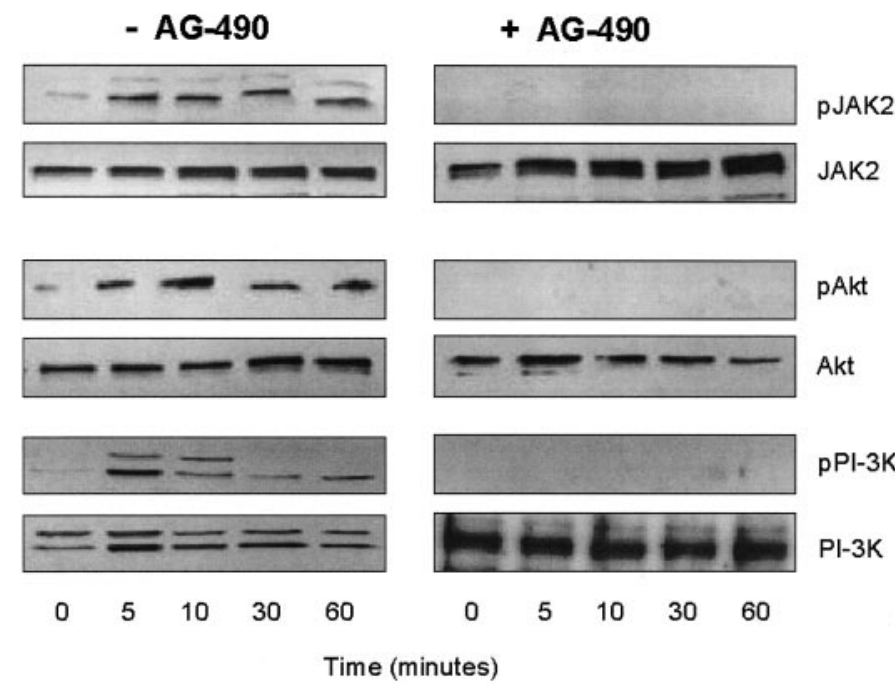

Fig. 4. TC-1698-induced activation of JAK2, Akt, and PI-3-kinase in PC12 cells in the presence or absence of AG-490. PC12 cells preincubated in the presence or absence of the JAK2 inhibitor AG-490 $(10 \mu \mathrm{M})$ were stimulated with $10 \mu \mathrm{M}$ TC-1698 for the time indicated. Cells were immunoblotted with phospho-specific and nonphosphospecific anti-JAK2 and anti-Akt antibodies or with anti-PI-3-kinase antibody. The PI-3kinase immunoprecipitated proteins were then immunoblotted with antiphosphotyrosine and anti-PI-3-kinase antibodies. Results shown for each immunoblot is representative of three immunoblots. 
A

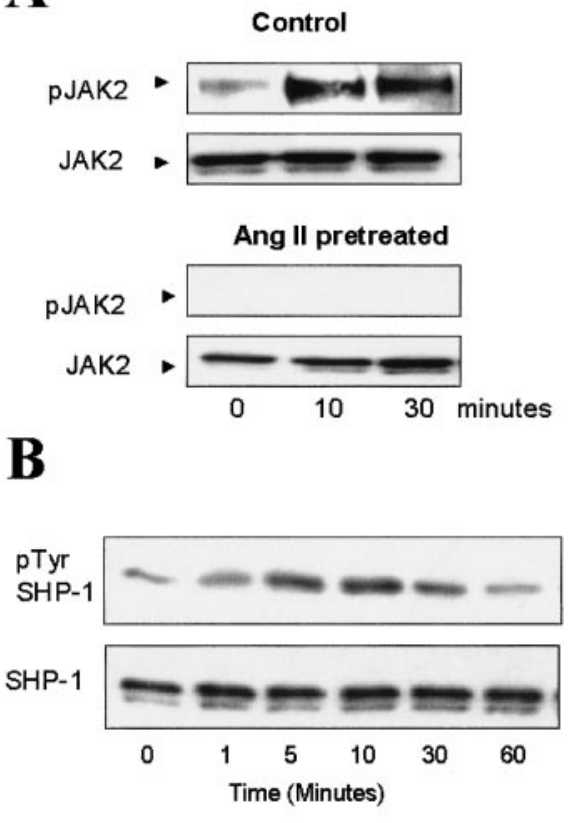

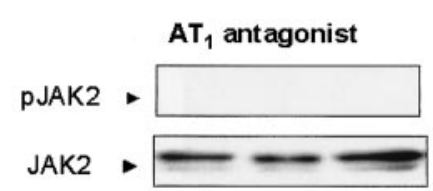
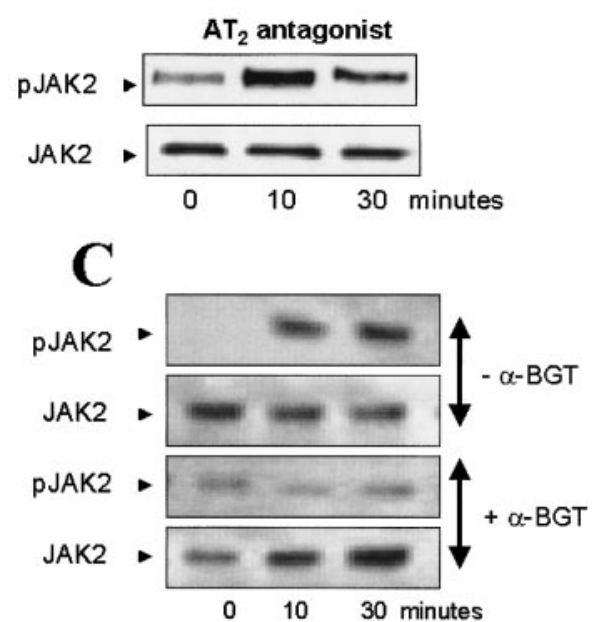

Fig. 5. A, effects of Ang II pretreatment with or without Ang II receptor antagonists on the TC1698-induced activation of JAK2 in PC12 cells. Cells preincubated with Ang II for $8 \mathrm{~h}$ in the presence or absence of $\mathrm{AT}_{1}$ antagonist candesartan or $\mathrm{AT}_{2}$ antagonist PD 123177 were stimulated with TC-1698 for the time indicated. Cells were immunoblotted with phospho-specific and nonphosphospecific anti-JAK2. Results shown for each immunoblot is representative of three immunoblots. B, angiotensin II-induced phosphorylation of SHP-1 in PC12 cells. PC12 cells were incubated for $24 \mathrm{~h}$ in serum-free medium before exposure to Ang II (100 nM) for the times indicated. Cells were lysed, and SHP-1 was immunoprecipitated from lysates with $10 \mu \mathrm{g} / \mathrm{ml}$ antiSHP-1 monoclonal antibodies and immuno-blotted with anti-phosphotyrosine antibody. Results shown for each immunoblot are representative of three immunoblots. C, effects of $\alpha$-bungarotoxin on TC1698-stimulated JAK2 phosphorylation. Cells preincubated with $0.1 \mu \mathrm{M} \alpha$-bungarotoxin or vehicle followed by addition of $0.1 \mu \mathrm{M}$ TC-1698 for the times indicated. Results shown for each immunoblot is representative of three immunoblots.

\section{Ang II-Induced Activation and Tyrosine Phosphorylation of SHP-1 and Its Effects on TC-1698-Induced Tyrosine Phosphorylation of JAK2}

The $\mathrm{AT}_{2}$ receptor exerts growth-inhibitory effects in cultured cells and in vivo, one of which has been proposed to be programmed cell death (Horiuchi et al., 1998; Lehtonen et al., 1999). Despite growing interest in $\mathrm{AT}_{2}$ receptor-mediated apoptosis, relatively little is known about the molecular basis of this process. Recently growth-inhibitory effects of the $\mathrm{AT}_{2}$ receptor have been reported to be mediated by the activation of PTPases, $\mathrm{AT}_{2}$ receptor stimulation is associated with a rapid activation of SHP-1 in rat pheochromocytoma $\mathrm{PC} 12$ cells (Horiuchi et al., 1998). However, at present, no functional role has been demonstrated for SHP-1 activation by the $\mathrm{AT}_{2}$ receptor, and it is interesting to note that SHP-1 has been shown to function as a negative regulator of JAK2 signaling (Marrero et al., 1998). Therefore, the potential biological significance of $\mathrm{AT}_{2}$ receptor-induced programmed cell death led us to investigate whether SHP-1 activation could be involved in this process. We found that Ang II induced both the tyrosine phosphorylation and activation of SHP-1 (Fig. 5B) and that vanadate, a specific inhibitor of PTPases (Marrero et al., 1996), blocked the activation of SHP-1 directly (Fig. 6). Furthermore, vanadate also augmented TC-1698-induced tyrosine phosphorylation of JAK2 (Fig. 6).

\section{Antisense against SHP-1 and Its Effects on TC-1698- Induced Tyrosine Phosphorylation of JAK2 in PC12 Cells}

Because vanadate is not a specific inhibitor of SHP-1, we also tested the effect of SHP-1 antisense phophorothiorate oligonucleotide on SHP-1 expression in PC12 cells. Cells were treated with the sense, or antisense oligonucleotides $(10 \mu \mathrm{M})$ for various times, SHP-1 was immunoprecipitated, and the immunoprecipitates were immunoblotted with anti-SHP-1 antibody. As shown in Fig. 7A, the antisense (but not the sense) oligonucleotide was effective in completely inhibiting SHP-1 expression within $12 \mathrm{~h}$. We then tested whether these antisense oligos could be used to regulate the TC-1698-induced activation JAK2 in PC12 cells. PC12 cells were stimulated with Ang II and lysed. JAK2 was then immunoprecipitated from lysates with anti-JAK2 antibody. Immunoprecipitated proteins were separated by gel electrophoresis, transferred to nitrocellulose, and then immunoblotted with anti-phosphotyrosine antibody. As a control, cells were exposed to SHP-1 sense oligonucleotide. As shown in Fig. 7B, when cells were exposed to the SHP-1 antisense form $12 \mathrm{~h}$, JAK2 tyrosine phosphorylation was augmented. These results suggest that SHP-1 is the PTPase that dephosphorylates JAK2 after TC-1698-induced JAK2 phosphorylation in PC12 cells.

\section{Assessment of PC12 Cell Apoptosis}

Apoptosis was determined by assessing the cleavage of the DNA-repairing enzyme PARP using a Western blot assay. PC12 cells were treated with $0.1 \mu \mathrm{M} \mathrm{A} \beta$ for $8 \mathrm{~h}$ in the presence or absence of TC-1698 $(10 \mu \mathrm{M})$. As shown in Fig. 8, PARP $(116 \mathrm{kDa})$ was cleaved to its $85-\mathrm{kDa}$ fragment after $\mathrm{A} \beta$ (1-42) treatment. The $\mathrm{A} \beta$ (1-42)-induced cleavage of PARP was blocked by TC-1698, which was prevented by preincubation with AG-490 or Ang II (Fig. 8). Further 12-h pretreatment with SHP-1 antisense, but not sense, completely prevented the cleavage of PARP (compare lanes 8 and 10). These results support our main hypothesis, which states that JAK2 plays a central role in the nicotinic $\alpha 7$ receptor-induced neuroprotection, which Ang II blocks through the $\mathrm{AT}_{2}$ receptor activation of the PTPase SHP-1.

Apoptosis was also determined by activation of caspase 3 . Caspase 3 is expressed in PC12 cells and is known to be involved in apoptosis (Shaw et al., 2002). Therefore, we examined caspase 3 activity after Ang II-induced apoptosis. We used the fluorescent peptide substrate Ac-DEVD-7AMC to measure caspase 3-like activity in cell lysates. As shown in Fig. 9, the caspase 3-like activity that resulted in the cleavage of the peptide substrate Ac-DEVD-7AMC is evident after $2 \mathrm{~h}$ of Ang II treatment and increased over time until it 
Without Vanadate

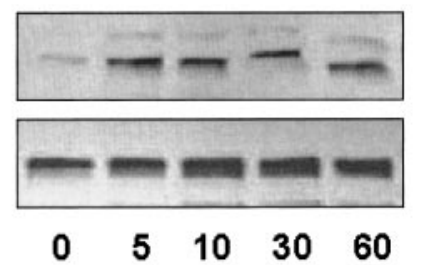

\section{With Vanadate}

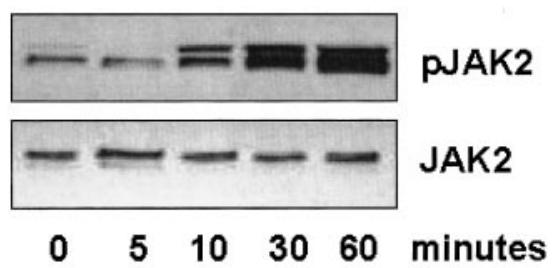

B

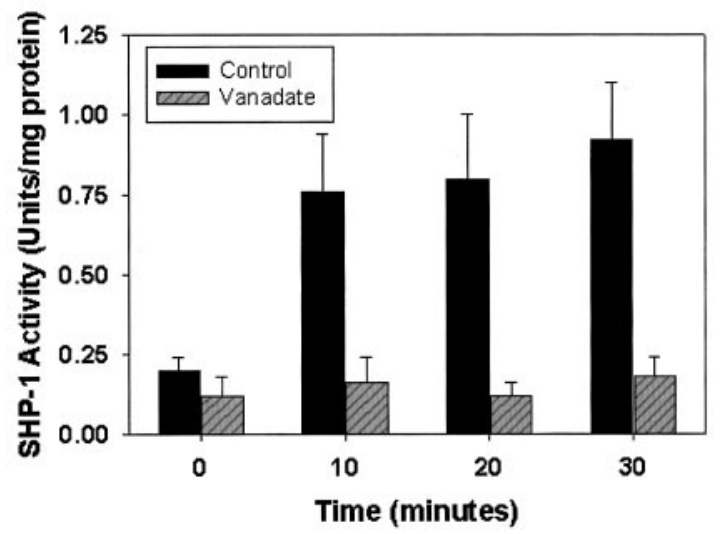

Fig. 6. A, TC-1698-induced activation of JAK2 in PC12 cells in the absence or presence of vanadate. PC12 cells preincubated in the presence or absence of the tyrosine phosphatase vanadate were stimulated with TC-1698 for the times indicated. Cells were immunoblotted with phosphospecific and nonphospho-specific anti-JAK2. B, time-dependent increase in SHP-1 activity in the absence or presence of vanadate. Results shown for each immunoblot is representative of three immunoblots. reached a peak after $8 \mathrm{~h}$ of treatment. However, the Ang II-induced activation of caspase 3 was blocked significantly in the presence of SHP-1 antisense $(+, P<0.01)$ or vanadate (*, $P<0.01$ ) (Fig. 9). Coincubation with the SHP-1 sense had no effect on the Ang II-induced activation of caspase 3. In addition, incubation with TC-1698 had also no effect caspase 3 activation (Fig. 9 ).

\section{Discussion}

In this study, we found that TC-1698, a novel $\alpha 7$-selective ligand, exerted neuroprotective effects via activation of the JAK2/PI-3K cascade, which can be neutralized through activation of the Ang II $\mathrm{AT}_{2}$ receptor. The Ang II $\mathrm{AT}_{2}$ receptor effects are reversed by nullifying a PTPase as evidenced by the usage of the PTPase-specific inhibitor vanadate (Marrero et al., 1996). Vanadate not only augmented the TC-1698induced tyrosine phosphorylation of JAK2 but also blocked the Ang II neutralization of TC-1698-induced neuroprotection against $\mathrm{A} \beta$ (1-42)-induced cleavage of PARP. Furthermore, when we also neutralized SHP-1 via antisense transfection the Ang II neutralization of TC-1698-induced neuroprotection against $\mathrm{A} \beta$ (1-42) was again blocked. These results support our main hypothesis, which states that JAK2 plays a central role in the nicotinic $\alpha 7$ receptor-induced activation of the JAK2-PI-3K cascade in PC12 cells, which ultimately contribute to nAChR-mediated neuroprotection. Furthermore, we also found that Ang II blocked this pathway through the $\mathrm{AT}_{2}$ receptor activation of SHP-1 (Fig. 10).

TC-1698 was relatively potent as an antagonist of the ACh responses of $\alpha 4 \beta 2$ receptors, apparently working through a competitive mechanism. TC-1698 also blocked subsequent ACh control responses of $\alpha 4 \beta 2$ and $\alpha 3 \beta 2$ receptors after it was applied in the absence of ACh. Interestingly, TC-1698 seems to be a full potent agonist only for the $\alpha 7$ receptors.
TC-1698 should predominantly activate $\alpha 7$ and inhibit $\alpha 4 \beta 2$ with relatively little effect on other receptors. TC-1698 seems to be a weak partial agonist/antagonist of beta subunit-containing neuronal receptors. The studies were conducted in PC12 cells with similar effects to those observed in human SH-SY5Y cells. Both of these cell lines exhibit $\alpha 7$ - and $\alpha 3 \beta 4$ containing receptors and TC-1698 interacts with the former but not the latter.

Several reports have documented the apoptotic effects of Ang II through $\mathrm{AT}_{2}$ receptors. $\mathrm{AT}_{2}$ receptors are expressed in PC12 and have been shown to inhibit the JAK/STAT signaling cascade (Kunioku et al., 2001). In contrast to nicotineinduced neuroprotection against $\beta$-amyloid (1-42), pretreatment of cells with Ang II blocks nicotine-induced activation of JAK2 via the $\mathrm{AT}_{2}$ receptor and completely prevents nicotinemediated neuroprotective effects, further suggesting a pivotal role for JAK2 phosphorylation (Shaw et al., 2002). Our findings in this study are consistent with the opposite roles on cell viability that exist between the $\alpha 7 \mathrm{nAChR}$ and the $\mathrm{AT}_{2}$ receptor with activation of the $\mathrm{AT}_{2}$ receptor overriding the potential benefit through the $\alpha 7 \mathrm{nAChR}$. These results and the convergence of these pathways on phosphorylated JAK2 suggest that recruitment of nicotinic $\alpha 7 \mathrm{nAChR}$ receptor-mediated neuroprotection against $\mathrm{A} \beta$ (1-42) may be optimized under conditions where the $\mathrm{AT}_{2}$-mediated inhibition is minimized by blocking the $\mathrm{AT}_{2}$-induced activation of the PTPase SHP-1. Therefore, the findings in this study identify novel molecular mechanisms, which are fully consistent with the role attributed to $\alpha 7 \mathrm{nAChR}$-induced activation of JAK2 and subsequent neuroprotective effect, $\mathrm{AT}_{2}$-induced activation of SHP-1, and its purported role in apoptotic events.

SHP-1 is a soluble tyrosine phosphatase that participates in the negative regulation of the tyrosine kinase JAK2 (Marrero et al., 1998), and it has been recently reported that 


\section{A SHP-1}
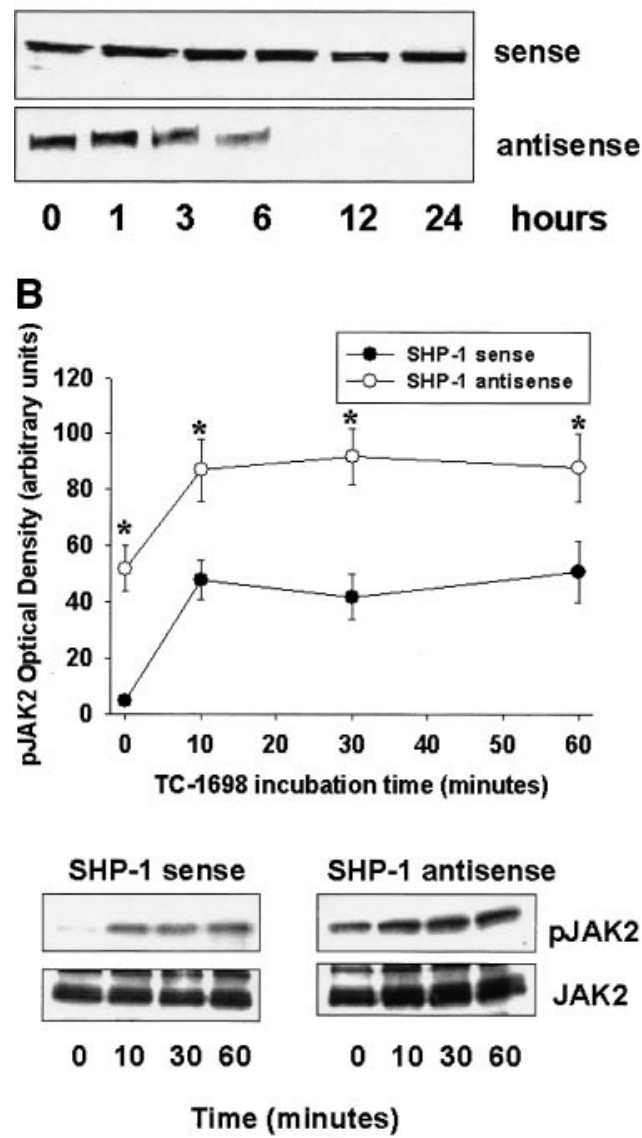

Fig. 7. A, effects of SHP-1 sense and antisense oligonucleotides on SHP-1 expression in PC12 cells. PC12 cells were treated with SHP-1 sense and antisense oligonucleotides for the times indicated and lysed. SHP-1 was immunoprecipitated from the lysates with anti-SHP-1 antibody. Precipitated SHP-1 proteins were then immunoblotted with specific anti-SHP-1 antibody. Results shown for each immunoblot are representative of three immunoblots. B, effects of SHP-1 antisense on the TC-1698-induced activation of JAK2 in PC12 cells. Cells preincubated in the presence or absence of SHP-1 antisense or sense oligonucleotides were stimulated with TC-1698 for the times indicated. Cells were immunoblotted with phospho-specific and nonphospho-specific anti-JAK2. Results shown for each immunoblot are representative of three immunoblots.

stimulation of $\mathrm{AT}_{2}$ receptors rapidly activates SHP-1 in N1E115 and $\mathrm{AT}_{2}$-transfected Chinese hamster ovary cells (Horiuchi et al., 1998; Lehtonen et al., 1999). In the present study, we document that the Ang II AT ${ }_{2}$ receptor activates SHP-1 in PC12 and that the TC-1698-induced activation of JAK2 is augmented by SHP-1 antisense transfection. These results suggest that both SHP-1 activation and JAK2 deactivation constitute sequential events in the same signaling pathway.

Nicotinic neurotransmission is compromised in the brains of Alzheimer's disease patients and accumulating evidence suggests that $\mathrm{nAChR}$-selective ligands can offer neuroprotective effects in several in vitro models, including neuronal death resulting from $\beta$-amyloid toxicity, $N$-methyl-D-aspartate-mediated cytotoxicity, or growth factor deprivation, and in in vivo models, including chemically induced neurotoxicity (1-methyl-4-phenyl-1,2,3,6-tetrahydropyridine models and systemic kainic acid-induced excitotoxic effects). Nicotinic ligands reduce $\beta$-amyloid aggregation and toxicity and inhibit amyloid deposition in transgenic mice with APPsw (Nordberg et al., 2002). A recent report has demonstrated
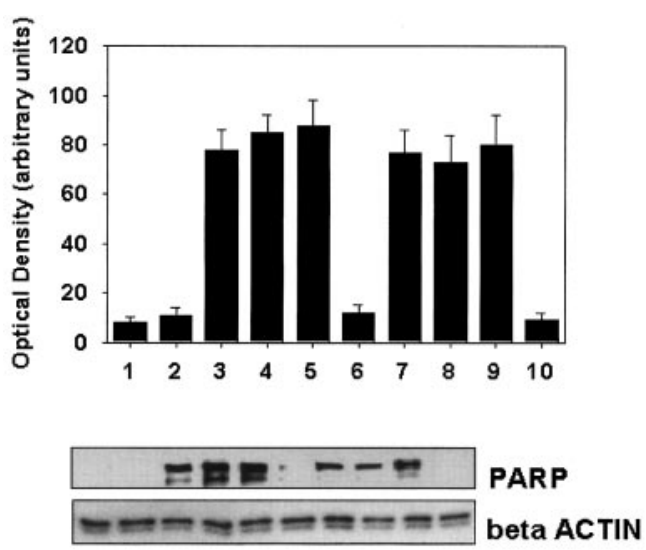

$\begin{array}{llllllllll}1 & 2 & 3 & 4 & 5 & 6 & 7 & 8 & 9 & 10\end{array}$

1. Control

2. TC-1698

3. ABeta (1-42)

4. $A G-490$

5. Angiotensin II

6. ABeta (1-42) + TC-1698

7. ABeta (1-42) + TC-1698 + AG-490

8. ABeta (1-42) + TC-1698 + Angiotensin II

9. ABeta (1-42) + TC-1698 + Angiotensin II + SHP-1 sense

10. Abeta (1-42) + TC-1698 + Angiotensin II + SHP-1 antisense

Fig. 8. Effects of SHP-1 antisense on TC-1698-induced protection against $\mathrm{A} \beta$ - and Ang II-induced apoptosis. PARP expression was measured from lysates of cells treated with $\mathrm{A} \beta$ (1-42) peptide and/or Ang II in the presence or absence of TC-1698 and/or SHP-1 antisense. Results shown for each immunoblot are representative of three immunoblots.

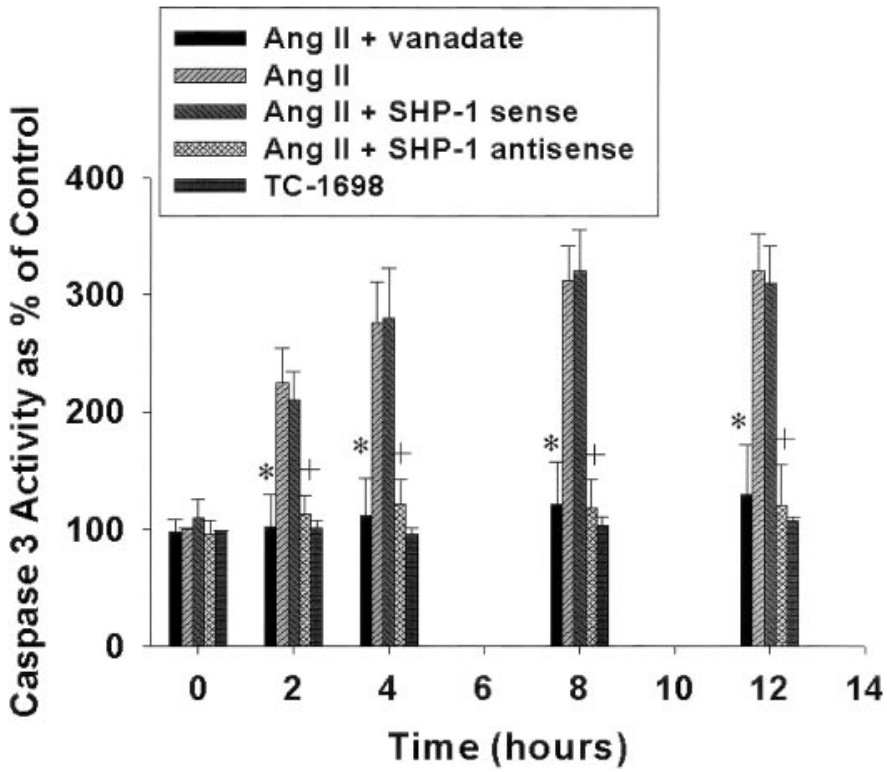

Fig. 9. Effects of SHP-1 antisense on the angiotensin II-induced activation of caspase-3. PC12 cells were incubated for the duration shown with Ang II in the presence of either SHP-1 antisense or SHP-1 sense or vanadate. Caspase- 3 activities are shown as the mean \pm S.E. of six independent cultures.

that the $\alpha 7 \mathrm{nAChR}$ is also an essential regulator of inflammation and is required for inhibition of cytokine release (Wang et al., 2003). The physiological mechanism coined "the cholinergic anti-inflammatory pathway", which has been proposed to have major implications in immunology and therapeutics, remains unknown. The induction and resolution of inflammatory processes are the complex outcome of interplay 


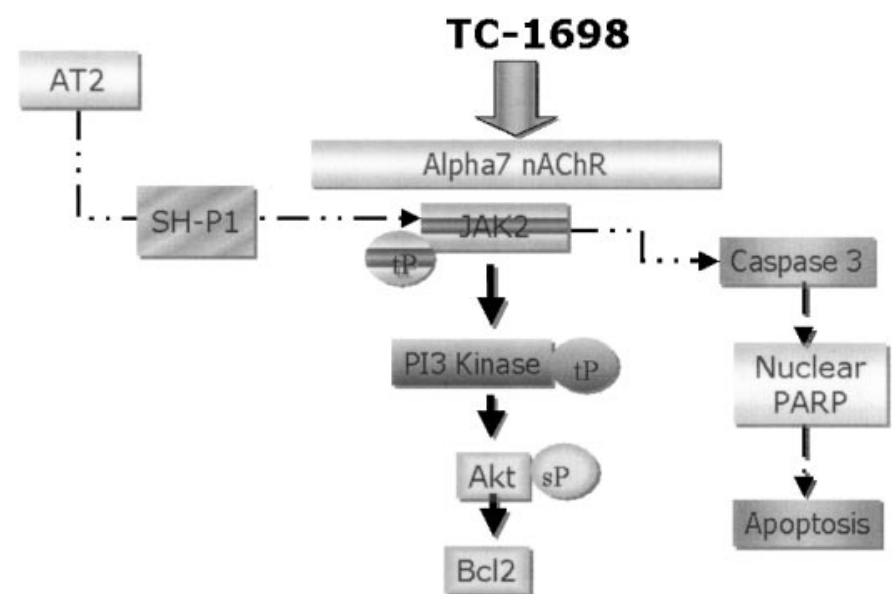

Fig. 10. Schematic of the protein tyrosine phosphatase SHP-1 inhibition of the $\alpha 7-\mathrm{JAK} 2$ survival pathway.

between pro- and anti-inflammatory cytokines. Pleiotropic cytokines such as IL-6 and IL-10 have been shown to activate the JAK-signal transducer and activator of transcription pathway and act in opposition to effects mediated by the proinflammatory cytokines IL-1 and tumor necrosis factor- $\alpha$ (Ahmed and Ivashkiv, 2000). It is conceivable from these findings that multifaceted therapeutic potential targeting cognitive deficits, neuroprotection, and inflammation in neurodegenerative diseases can be recruited through a single pharmacology targeting the $\alpha 7 \mathrm{nAChR}$. It remains to be established whether similar pathways are operative for these various end-points in vivo and whether the negative influence of $\mathrm{AT}_{2}$ stimulation is clinically relevant. However, the putative beneficial effects of angiotensin-converting enzyme inhibitors in Alzheimer's disease and the observation of selective up-regulation of $\mathrm{AT}_{2}$ receptor density (Ge and Barnes, 1996) and biosynthetic enzymes (Narain et al., 2000; Savaskan et al., 2001) concurrent with down-regulation of nAChR in the temporal cortex of some Alzheimer's disease patients (Court et al., 2001) are consistent with the opposite effects on cell viability observed in our studies through activation of $\mathrm{AT}_{2}$ and $\alpha 7-\mathrm{nAChR}$.

\section{Acknowledgments}

We thank Julia Porter Papke, Irena Garic, Bernadette Schoneburg, and Clare Stokes for technical assistance. We are very grateful to Axon Instruments for the use of an OpusXpress 6000A and pClamp 9. We particularly thank Dr. Cathy Smith-Maxwell for support and help with OpusXpress.

\section{References}

Ahmed ST and Ivashkiv LB (2000) Inhibition of IL-6 and IL-10 signaling and Stat activation by inflammatory and stress pathways. J Immunol 165:5227-5237.

Bencherif M, Lovette ME, Fowler KW, Arrington S, Reeves L, Caldwell WS, and Lippiello PM (1996) RJR-2403: a nicotinic agonist with CNS selectivity I. In vitro characterization. J Pharmacol Exp Ther 279:1413-1421.

Bencherif M and Schmitt JD (2002) Targeting neuronal nicotinic receptors: a path to new therapies. CNS Neurol Disord 1:319-327.

Breese CR, Adams C, Logel J, Drebing C, Rollins Y, Barnhart M, Sullivan B, Demasters BK, Freedman R, and Leonard S (1997) Comparison of the regional expression of nicotinic acetylcholine receptor alpha7 mRNA and [125I]-alphabungarotoxin binding in human postmortem brain. J Comp Neurol 387:385-398.

Court J, Martin-Ruiz C, Piggott M, Spurden D, Griffiths M, and Perry E (2001) Nicotinic receptor abnormalities in Alzheimer's disease. Biol Psychiatry 49:175184.
Davies AR, Hardick DJ, Blagbrough IS, Potter BV, Wolstenholme AJ, and Wonnacott S (1999) Characterization of the binding of $[3 \mathrm{H}]$ methyllycaconitine: a new radioligand for labelling alpha 7 -type neuronal nicotinic acetylcholine receptors. Neuropharmacology 38:679-690.

Dicou E, Attoub S, and Gressens P (2001) Neuroprotective effects of leptin in vivo and in vitro. Neuroreport 12:3947-3951.

Dineley KT, Westerman M, Bui D, Bell K, Ashe KH, and Sweatt JD (2001) Betaamyloid activates the mitogen-activated protein kinase cascade via hippocampal alpha7 nicotinic acetylcholine receptors: in vitro and in vivo mechanisms related to Alzheimer's disease. J Neurosci 21:4125-4133.

Donnelly-Roberts DL, Xue IC, Arneric SP, and Sullivan JP (1996) In vitro neuroprotective properties of the novel cholinergic channel activator (ChCA), ABT-418. Brain Res 719:36-44.

Ge J and Barnes NM (1996) Alterations in angiotensin AT1 and AT2 receptor subtype levels in brain regions from patients with neurodegenerative disorders. Eur J Pharmacol 297:299-306.

Horiuchi M, Akishita M, and Dzau VJ (1998) Molecular and cellular mechanism of angiotensin II-mediated apoptosis. Endocr Res 24:307-314.

Kem WR (2000) The brain alpha7 nicotinic receptor may be an important therapeutic target for the treatment of Alzheimer's disease: studies with DMXBA (GTS-21). Behav Brain Res 113:169-181.

Kihara T, Shimohama S, Sawada H, Honda K, Nakamizo T, Shibasaki H, Kume T, and Akaike A (2001) alpha 7 Nicotinic receptor transduces signals to phosphatidylinositol 3-kinase to block A beta-amyloid-induced neurotoxicity. J Biol Chem 276:13541-13546.

Kitagawa H, Takenouchi T, Azuma R, Wesnes KA, Kramer WG, Clody DE, and Burnett AL (2003) Safety, pharmacokinetics and effects on cognitive function of multiple doses of GTS-21 in healthy, male volunteers. Neuropsychopharmacology 28:542-551.

Kunioku H, Inoue K, and Tomida M (2001) Interleukin-6 protects rat PC12 cells from serum deprivation or chemotherapeutic agents through the phosphatidylinositol 3-kinase and STAT3 pathways. Neurosci Lett 309:13-16.

Lehtonen JY, Daviet L, Nahmias C, Horiuchi M, and Dzau VJ (1999) Analysis of functional domains of angiotensin II type 2 receptor involved in apoptosis. Mol Endocrinol 13:1051-1060.

Liu Q, Kawai H, and Berg DK (2001) beta-Amyloid peptide blocks the response of alpha 7-containing nicotinic receptors on hippocampal neurons. Proc Natl Acad Sci USA 98:4734-4739.

Lukas RJ and Cullen MJ (1988) An isotopic rubidium ion efflux assay for the functional characterization of nicotinic acetylcholine receptors in clonal cell lines. Anal Biochem 175:212-218.

Marrero MB, Schieffer B, Bernstein KE, and Ling BN (1996) Angiotensin II-induced tyrosine phosphorylation in mesangial and vascular smooth muscle cells. Clin Exp Pharmacol Physiol 23:83-88.

Marrero MB, Venema VJ, Ju H, Eaton DC, and Venema RC (1998) Regulation of angiotensin II-induced JAK2 tyrosine phosphorylation: roles of SHP-1 and SHP-2. Am J Physiol 275:C1216-C1223.

Meydan N, Grunberger T, Dadi H, Shahar M, Arpaia E, Lapidot Z, Leeder JS, Freedman M, Cohen A, Gazit A, et al. (1996) Inhibition of acute lymphoblastic leukaemia by a Jak-2 inhibitor. Nature (Lond) 379:645-648.

Narain Y, Yip A, Murphy T, Brayne C, Easton D, Evans JG, Xuereb J, Cairns N, Esiri MM, Furlong RA, et al. (2000) The ACE gene and Alzheimer's disease susceptibility. J Med Genet 37:695-697.

Newhouse PA, Potter A, Kelton M, and Corwin J (2001) Nicotinic treatment of Alzheimer's disease. Biol Psychiatry 49:268-278.

Nordberg A, Hellstrom-Lindahl E, Lee M, Johnson M, Mousavi M, Hall R, Perry E, Bednar I, and Court J (2002) Chronic nicotine treatment reduces beta-amyloidosis in the brain of a mouse model of Alzheimer's disease (APPsw). J Neurochem 81:655-658.

Papke RL and Papke JKP (2002) Comparative pharmacology of rat and human $\alpha 7$ nAChR conducted with net charge analysis. Br J Pharmacol 137:49-61.

Romano C and Goldstein A (1980) Stereospecific nicotine receptors on rat brain membranes. Science (Wash DC), 210:647-650.

Savaskan E, Hock C, Olivieri G, Bruttel S, Rosenberg C, Hulette C, and MullerSpahn F (2001) Cortical alterations of angiotensin converting enzyme, angiotensin II and AT1 receptor in Alzheimer's dementia. Neurobiol Aging 22:541-546.

Sharlow ER, Pacifici R, Crouse J, Batac J, Todokoro K, and Wojchowski DM (1997) Hematopoietic cell phosphatase negatively regulates erythropoietin-induced hemoglobinization in erythroleukemic SKT6 cells. Blood 90:2175-2187.

Shaw S, Bencherif M, and Marrero MB (2002) Janus kinase 2, an early target of alpha 7 nicotinic acetylcholine receptor-mediated neuroprotection against Abeta(1-42) amyloid. J Biol Chem 277:44920-44924.

Wang H, Yu M, Ochani M, Amella CA, Tanovic M, Susarla S, Li JH, Wang H, Yang $\mathrm{H}$, Ulloa L, et al. (2003) Nicotinic acetylcholine receptor $\alpha 7$ subunits is an essential regulator of inflammation. Nature (Lond) 421:384-388.

Wang HY, Lee DH, D'Andrea MR, Peterson PA, Shank RP, and Reitz AB (2000) beta-Amyloid(1-42) binds to alpha7 nicotinic acetylcholine receptor with high affinity. Implications for Alzheimer's disease pathology. J Biol Chem 275:56265632 .

Address correspondence to: Dr. Merouane Bencherif, Targacept Inc., 200 East First St., Suite 300, Winston-Salem, NC 27101-4165. E-mail: merouane.bencherif@targacept.com 